University for Business and Technology in Kosovo

UBT Knowledge Center

Nov 7th, 9:00 AM - 5:00 PM

\title{
The effects of recycling asphalt use in terms of economic growth and environmental improvement in Kosova
}

\author{
Muhamet Ahmeti \\ University for Business and Technology, muhamet.ahmeti@ubt-uni.net \\ Binak Beqaj \\ University for Business and Technology, bbeqaj@ubt-uni.net
}

Follow this and additional works at: https://knowledgecenter.ubt-uni.net/conference

Part of the Civil Engineering Commons, and the Structural Engineering Commons

\section{Recommended Citation}

Ahmeti, Muhamet and Beqaj, Binak, "The effects of recycling asphalt use in terms of economic growth and environmental improvement in Kosova" (2015). UBT International Conference. 79.

https://knowledgecenter.ubt-uni.net/conference/2015/all-events/79

This Event is brought to you for free and open access by the Publication and Journals at UBT Knowledge Center. It has been accepted for inclusion in UBT International Conference by an authorized administrator of UBT Knowledge Center. For more information, please contact knowledge.center@ubt-uni.net. 


\title{
The effects of recycling asphalt use in terms of economic growth and environmental improvement in Kosova
}

\author{
Muhamet Ahmeti ${ }^{1}$, Binak Beqaj ${ }^{2}$ \\ ${ }^{1,2}$ Institution: UBT, Faculty of Architecture and Spatial Planning, Prishtina, Kosovo \\ \{muhamet.ahmeti ${ }^{1}$, bbeqaj ${ }^{2}$ @ubt-uni.net
}

\begin{abstract}
Through this paper is analysed the possibility of recycling asphalt and reusing this in receipts of new asphalt to build road infrastructure inside urban areas and inter-urban areas, because analy sing the investments that are being realized in the road infrastructure in Kosova last years, and investments that are going on, there are indicators showing economical, environmental and ....benefits of the society.

According to database of the Kosova Ministry of Transport and Telecommunication until the year 2014 , the territory of Kosova has $2005.5 \mathrm{~km}$ of the road, $4 \%$ are highway s, magisterial roads $32 \%$ and $64 \%$ regional roads, most of them should be reconstructed, so, the existing asphalt layers should be removed, and this layer has a thickness of $15-30 \mathrm{~cm}$, depending on category of road.

Positive expected effects from re-use of recycled asphalt can be treated through cost-benefit analy ses, especially through its direct impact on:

- Reducing massive exploration of our natural and other resources for producing asphalt

- Reducing production and use costs of asphalt

- Growing possibility for problem-solving through asphaltation of more roads in urban or periurban areas

- Minimizing of environmental degradation from asphalt waste

- Improving public health

However considering information, that level of asphalt recycling in Kosovo and in the region does not exceed more than 5\%, while the construction waste $10 \%$, it is the fact that this process should be treated seriously especially considering the fact that Kosova is a state under development and there is limited capacity for investment in road infrastructure considering mass needs.
\end{abstract}

Keywords: asphalt, road, infrastructure, investment, benefits.

\section{Introduction}

Through this paper is analyzed the possibility of recycling asphalt and reusing this in receipts of new asphalt to built road infrastructure inside urban areas and inter-urban areas, analyzing the investments that are being realized in the road infrastructure in Kosova last years, and investments that are going on, there are indicators showing economical, environmental and benefits of the societ. According to database of the Kosova Ministry of Transport and Telecommunication until the year 2014, the territory of Kosova has $2005.5 \mathrm{~km}$ of the road, $4 \%$ are highways, magistral roads $32 \%$ and $64 \%$ regional roads.

Most of the roads need to be reconstructed, so, the existing asphalt layers should be removed, and this layer has a thickness of 15-30 cm, depending on category of road and with medium dimension of 7 $\mathrm{m}$. Are of special importance of this work is the setting of the amount of asphalt that can be recycled, information are very important to know how much can be the amounts of recycling asphalt in Kosovo 


\subsection{State of motor vehicles in Kosovo}

In 2014 in Kosovo were registered about 289.000 motor and non-motor vehicles or $15.6 \%$ more than in 2013.

Tabela 1 Registered motor and non-motor vehicles Source of data: Department of Roads to Kosovo

\begin{tabular}{|l|c|c|c|c|}
\hline \multicolumn{1}{|c|}{ YEARS } & 2011 & 2012 & 2013 & 2014 \\
\hline Automobiles & 170,321 & 176,398 & 222,537 & 236,145 \\
\hline Transport vehicle,3.5 and over 3.5 & 10,877 & 11,547 & 15,352 & 15,769 \\
\hline Transport vehicle under 3.5t & 17,901 & 18,225 & 24,659 & 26,949 \\
\hline Minibus & 2,698 & 2,520 & 3,225 & 3,161 \\
\hline Buses & 1,117 & 1,298 & 1,570 & 1,697 \\
\hline Motorcycles & 546 & 809 & 1,488 & 1,540 \\
\hline Tractors & 39 & 137 & 776 & 1,036 \\
\hline Trailer under 3.5t & 101 & 117 & 217 & 250 \\
\hline Trailer 3.5 and above 3.5t & 1,766 & 1,800 & 2,283 & 2,281 \\
\hline Automobiles & $\mathbf{2 0 5 , 3 6 6}$ & $\mathbf{2 1 2 , 8 5 1}$ & $\mathbf{2 7 2 , 1 0 7}$ & $\mathbf{2 8 8 , 8 2 8}$ \\
\hline
\end{tabular}

\subsection{Roads of Kos ovo}

Since the end of war and until 2014, capital investments were made in the construction of roads in Kosovo,since investments are ongoing, new classification of roads are not completed.

The respective board of directors makes classification of roads, by construction standards. KAS (Kosovo Agency of Statistics \} by the Department of Roads to Kosovo took only changs in the length of paved and not paved roads for 2009 and 2010, and in 2011 was added motorway length of $38 \mathrm{~km}$. In 2012 were aded $22.4 \mathrm{~km}$, and in 2013 was added $17.6 \mathrm{~km}$ route length of the motorway and now 3 motorway road length is $78 \mathrm{~km}$.

Table 2 Kosovo's roads by category (Source of data: Department of Roads to Kosovo.)

\begin{tabular}{|l|r|r|r|r|r|r|r|r|r|r|}
\hline & 2005 & 2006 & 2007 & 2008 & 2009 & 2010 & 2011 & 2012 & 2013 & 2014 \\
\hline Paved & $1,666.2$ & $1,666.2$ & $1,666.2$ & $1,666.2$ & $1,805.0$ & $1,805.0$ & $1,843.0$ & $1,865.4$ & $1,883.0$ & $1,883.0$ \\
\hline $\begin{array}{l}\text { Not } \\
\text { paved }\end{array}$ & 258.9 & 258.9 & 258.9 & 258.9 & 120.1 & 120.1 & 120.1 & 120.1 & 120.1 & 120.1 \\
\hline Total & $\mathbf{1 , 9 2 5 . 1}$ & $\mathbf{1 , 9 2 5 . 1}$ & $\mathbf{1 , 9 2 5 . 1}$ & $\mathbf{1 , 9 2 5 . 1}$ & $\mathbf{1 , 9 2 5 . 1}$ & $\mathbf{1 , 9 2 5 . 1}$ & $\mathbf{1 , 9 6 3 . 1}$ & $\mathbf{1 , 9 8 5 . 5}$ & $\mathbf{2 , 0 0 3 . 1}$ & $\mathbf{2 , 0 0 3 . 1}$ \\
\hline
\end{tabular}

According to data presented, it shows that in 2013 and 2014 in the territory of Kosovo we have 2003.1 $\mathrm{km}$, the category of roads Motorway $4 \%$, National $31 \%$, while $65 \%$ are regional roads.

The table above shows that in the year 2014 a total of $2,003.1 \mathrm{~km}$ of roads $1,883.0 \mathrm{~km}$ or in percentage $94 \%$ are paved (asphalted), while $120.1 \mathrm{~km}$ or $6 \%$ of the roads are not paved.

Table 3 Kosovo's roads by category - in kilometers $(\mathrm{km})$ - Source of data: Department of Roads to Kosovo)

\begin{tabular}{|l|r|r|r|r|r|r|r|r|r|r|}
\multicolumn{4}{c}{2005} & \multicolumn{2}{c}{2006} & \multicolumn{2}{c}{2007} & \multicolumn{2}{c}{2008} & \multicolumn{2}{c}{2009} & 2010 & 2011 & 2012 & 2013 & \multicolumn{1}{c}{2014} \\
\hline Motorway & 0 & 0 & 0 & 0 & 0 & 0 & 38 & 60.4 & 78 & 78 \\
\hline National & 630.4 & 630.4 & 630.4 & 630.4 & 630.4 & 630.4 & 630.4 & 630.4 & 630.4 & 630.4 \\
\hline Regional & $1,294.7$ & $1,294.7$ & $1,294.7$ & $1,294.7$ & $1,294.7$ & $1,294.7$ & $1,294.7$ & $1,294.0$ & $1,294.7$ & $1,294$. \\
\hline Total & $\mathbf{1 , 9 2 5 . 1}$ & $\mathbf{1 , 9 2 5 . 1}$ & $\mathbf{1 , 9 2 5 . 1}$ & $\mathbf{1 , 9 2 5 . 1}$ & $\mathbf{1 , 9 2 5 . 1}$ & $\mathbf{1 , 9 2 5 . 1}$ & $\mathbf{1 , 9 6 3 . 1}$ & $\mathbf{1 , 9 8 5 . 5}$ & $\mathbf{2 , 0 0 3 . 1}$ & $\mathbf{2 , 0 0 3 . 1}$ \\
\hline
\end{tabular}


Table 4. Percentage of investment in infrastructure from 2005 to 2015

\begin{tabular}{|l|c|c|c|c|c|c|c|c|c|}
\hline $\begin{array}{l}\text { Infrastructure } \\
\text { investment in the } \\
\text { years since 2005 }\end{array}$ & 2006 & 2007 & 2008 & 2009 & 2010 & 2011 & 2012 & 2013 & 2014 \\
\hline Change in \% & $0 \%$ & $0 \%$ & $0 \%$ & $8.3 \%$ & $8.3 \%$ & $10.7 \%$ & $12 \%$ & $13 \%$ & $13 \%$ \\
\hline
\end{tabular}

As are analyzed the investments in road infrastructure from 2005 to 2014 , the percentage of investments in years comperin with 2005 years, so we have analyzed the percentage increase in the number of vehicles in Kosovo having a focus from 2012 until 2014.

Table 2 Increase the percentage of road construction and the growing number of vehicles since 2011

\begin{tabular}{|l|c|c|c|}
\hline $\begin{array}{l}\text { Increase the percentage of roadconstructionandthe } \\
\text { growing number of vehicles since 2011 }\end{array}$ & 2012 & 2013 & 2014 \\
\hline Percentage increase in the number of vehicles & $3.6 \%$ & $32 \%$ & $41 \%$ \\
\hline The percentage of road construction & $1,3 \%$ & $2,3 \%$ & $2,3 \%$ \\
\hline
\end{tabular}

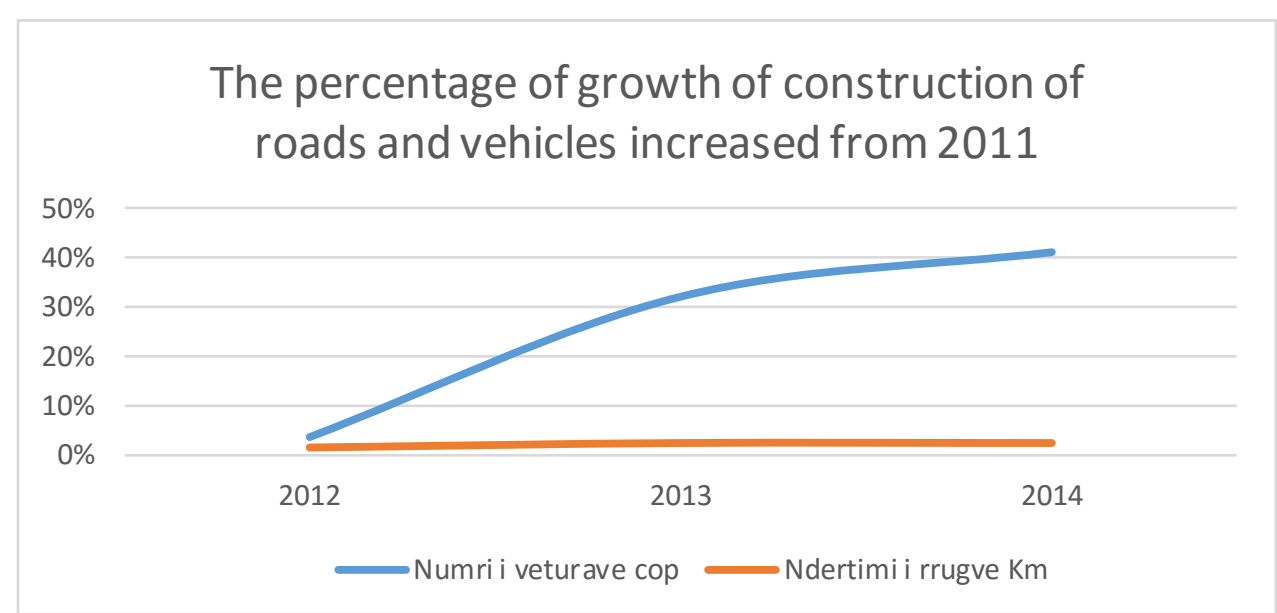

Figure 1 The graphic presentation of the difference between of investment in the roads and growth in the number of vehicles

\subsection{Because of this increase, can be concluded:}

1. Increase the number of vehicles compared with the increase in road investment is more pronounced 2. Increase very large number of vehicles compared with the increase in road investment, growth necessitates strips of roads

3. Investments slow compared with the increasing number of vehicles leads to blockage of traffic and numerous problems in traffic

4. From these changes is necessary expansion of existing roads as and have started Pristina Mitrovica, Peja Prishtina, Prishtina - Gjilan are also many other ways to increase vehicle demand and obliges us to expand existing routes.

5. In most cases, extensions are accompanied by a complete new track of the road.

1.22 The situation in areas where road extension done - The need to build new roads and highways each time more and more will be reduced, the more important will be the management, maintenance, and expansion of roads and highways to be builded. 
Each time we load the bulk of the increased traffic loads with which to cope roads constructed, these loads lead to damage to the roads and highways in the form of cuts and cracks and other forms of damage.

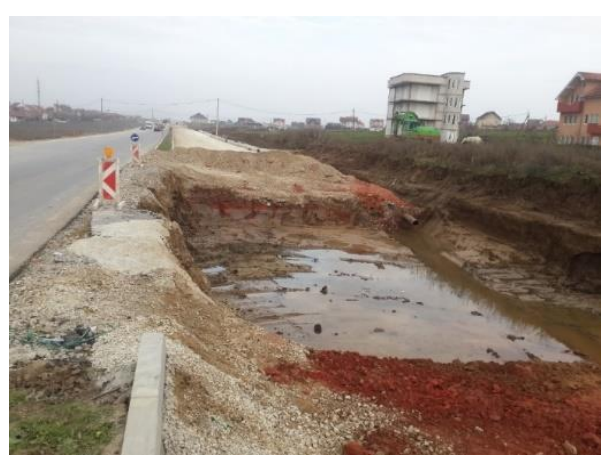

Fig 1. The condition in road expansion Pristina - Mitrovica

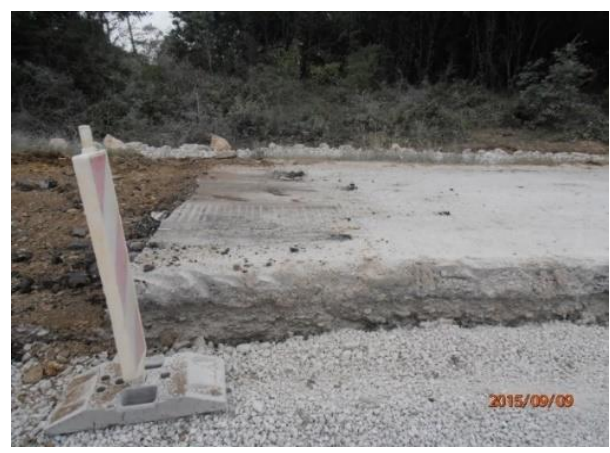

Fig 2. Condition of roads expansion of Skenderaj - Komoran

Until recently with the asphalt road maintenance, is mplied Novel building layers of asphalt material leveler of bitenemizuar and the abrasion layer of asphalt concrete? It is believed that there are limited resources and enough of the material for the construction and maintenance of roads, but costs explant requirements for storage facilities and transport costs of natural stone to plant asphalt has changed the opinion of the former and have begun and proceeded to seek other methods more efficient and lower cost and more effective for replacement of natural materials. One of the methods that were used in the years since the thirties is the method of recycling the materials used in the construction of roads and highways of asphalt and asphalt concrete (PAR - Reclaimed Asphalt Pavement). Accounts in the world for a year produced more than 500 million tons of material.

Table 6 Available reclaimed asphalt (tonnes), source european asphalt pavement, www.eapa.org association

\begin{tabular}{|l|r|c|}
\hline \multicolumn{1}{|c|}{ Country } & $\begin{array}{c}\text { Available reclaimed } \\
\text { asphalt (tonnes) }\end{array}$ & $\begin{array}{c}\text { \% of the new hot and warm mix production } \\
\text { that contains reclaimed material }\end{array}$ \\
\hline Austria & 750.000 & 51 \\
\hline Belgium & 1.500 .000 & 10 \\
\hline Czech Republic & 1.450 .000 & 58 \\
\hline Denmark & 790.000 & $>65$ \\
\hline France & 6.900 .000 & \\
\hline Germany & 11.500 .000 & 20 \\
\hline Great Britain & $4.000 .000-5.000 .000$ & 50 \\
\hline Hungary & 88.000 & 70 \\
\hline Italy & 10.000 .000 & 20 \\
\hline Luxembourg & 300.000 & 70 \\
\hline Netherlands & 4.500 .000 & 27 \\
\hline Norway & 686.268 & 76 \\
\hline Sweden & 900.000 & \\
\hline Switzerland & 1.370 .000 & \\
\hline Japan & 69.000 .000 & \\
\hline U.S.A. & & \\
\hline D. & & \\
\hline
\end{tabular}

Denmark, Norway, Germany have use of material RAP to produce new lay ers of asphalt with greater than 50\%, the same notes have also in Japan and the UK, while in Kosovo, exploitation and use of the material PAR for production of layers New asphalt has a negligible level.

Recycling of aphalt road that allows us to use material for paper behind them and constructing roads. Economic conditions, fair legal requirements, and the development of technological equipment for the production of asphalt have conditioned us and enable recycling of asphalt. 
Limited quantities of natural aggregates high prices of oil products are the economic conditions that have led to new technologies and new techniques to carry out works in the recycling of materials.

Laws in force and promote recycling and re-use of this material, it reduces the appearance of waste and reduces the emission of $\mathrm{CO} 2$ and are prescribed severe penalties for violators of these laws.

According origin-recycled asphalt can be:

- Endogen - which comes from the same street which is recycled or

- EGZOGEN - when father brought from another place in the country of recycling.

Methods of recycling asphalt in road constructions divided into two main categories:

- Method, which uses stationary base driving (in plant)

- Method, which is realized in the country (in place).

In addition, these two methods of recycling may be depending on the temperature of the asphalt work and that makes to separate the two other categories:

- Method of recycling heated

- Cold recycling method

Strengths and weaknesses of the leading recycling categories have been presented to the following:

\section{Recycling places.}

Advantages:

$\square$ High quality of the recy cled mix,

$\neg$ Possibility of controlling the granulometrise,

$\square$ Very homogeny measure,

$\square$ Sizing opportuto measure and mix,

$\square$ Use of recy cling bitumen,

$\square$ reuse in addition abrasive asphalt,

$\square$ A high flexibility of use,

Disadvantages: potential options with high costs

$\square$ Very large expenditure of energy

$\square$ Greater participation of the material transport

$\square$ Storage of recycled material RAP

Damage to the environment - emitions $\mathrm{CO}_{2}$

\section{Recycling base station for recycling.}

Advantages: use of full of material RAP

$\square$ Introduction in view of fast roads,

$\square$ suited for projects large and small,

$\square$ Economic influence,

$\square$ to reduce transportation costs,

possibility of committing to recy cling only a circular track

Gaps: necessary a surface layer

$\square$ Homogenization problem presented us new asphalt on the existing

$\square$ long recy cling are not suitable for the small streets and rural roads

$\square$ Simple technology and equipment is only suitable to rural roads and streets with small volume 
The laws in Kosovo do not encourage recycling and the use of reuse of this material, which is very different from the regional countries and European countries that by law companies for the production of asphalt promote and stimulate the use of asphalt recycled for reuse,

Using recycled asphalt in the countries where it is prescribed by law reduces the appearance of waste and reduces $\mathrm{CO} 2$ emissions, and are provided for severe penalties for violators of these laws Përdorimi i asfaltit

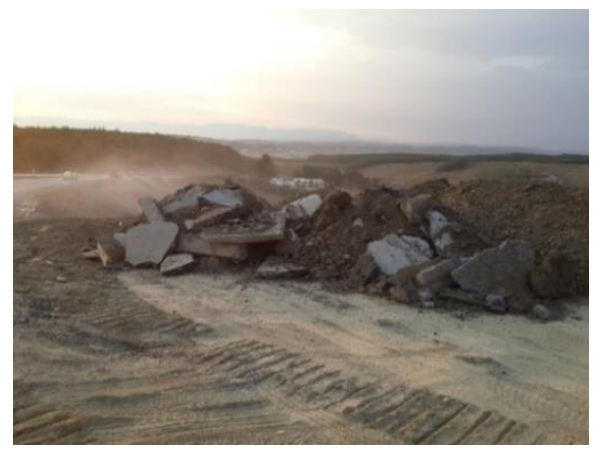

Fig 3. Collection of waste asphalt removed from track to expand - Polac - Skenderaj

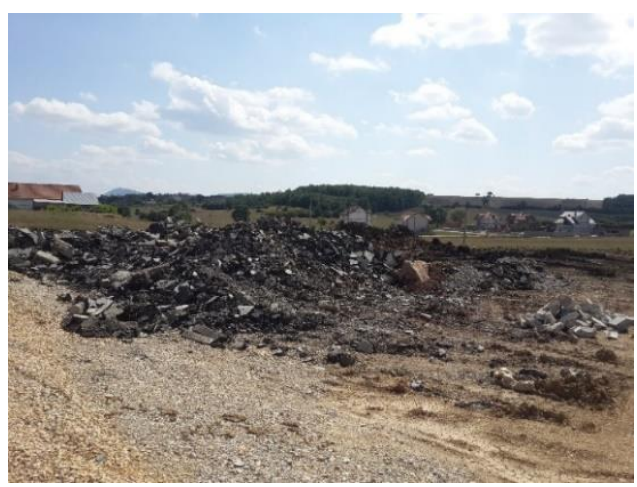

Fig 5. Waste of the removed asphalt layer on the road expanding Skenderaj - Komoran

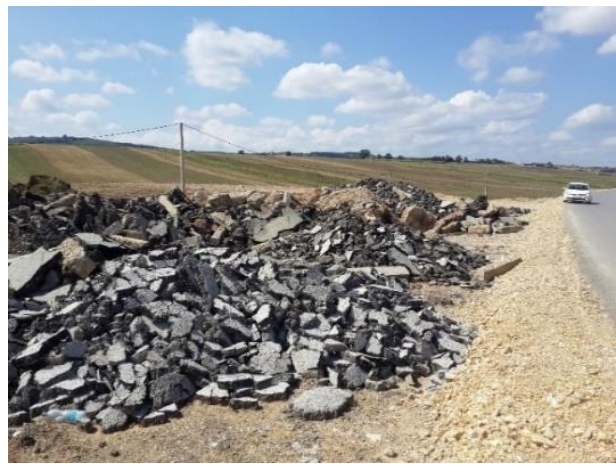

Fig 4. Waste of the removed asphalt layer on the road expanding Skenderaj - Komoran

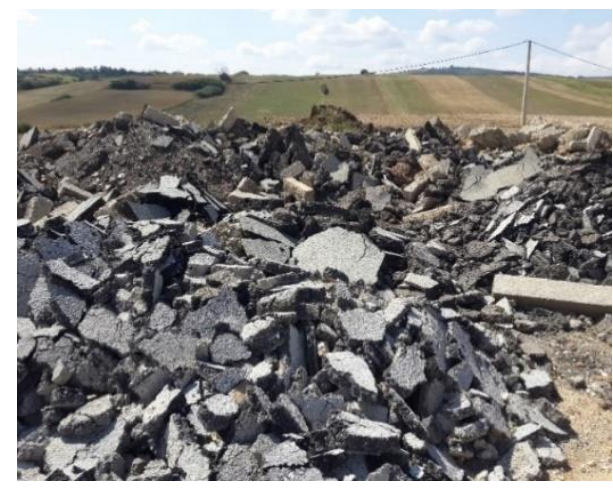

Fig 6. Waste of the removed asphalt layer on the road expanding Skenderaj - Komoran

In these works we have used several experiments which are analyzed with recycling asphalt as well as the ducts of the new asphalt, in order to compare curves granulometric and the amount of Bitulitit to asphalt recycling in this case was taken findings in this laboratory, experiments are conducted in the laboratory for building materials of the company „Koteks,, city Osijek in Croatia as well ,

The results and recapture of the new asphalt are similar with recapture's for the preparation of the new asphalt in „Renelual company , city of Prizren, Kosovo. Why have used this laboratory tests with recycled asphalt in company, Koteks, city Osijek in Croatia .

After that existing asphalt is working based on these receptures, therefore the results obtained are simulated with the results to be won in the laboratories of reviewing the materials in Kosovo.

Laboratory in Croatia are performing physical examinations de mechanical samples of asphalt mix asphalt with recycled quantities.In general, we found that the preparation of asphalt receipts are the same as granulometria as well as other components that we need for the preparation of asphalt. 
Table 7. Presentation of granulometric curves designed in Croatia and Kosovo.

\begin{tabular}{c|r|r|r|r|r|r|r|r|r|r}
$\begin{array}{c}\text { curve } \\
\text { respectiv } \\
\text { e }\end{array}$ & 0.09 & 0.25 & 0.71 & 2 & 4 & 8 & 11.2 & 16 & 22.4 & 31.5 \\
\hline Kosove & 12 & 18 & 27 & 40 & 52 & 68 & 78 & 90 & 100 & 100 \\
\hline Kroacia & 13.3 & 17.4 & 27.4 & 47.2 & 66.6 & 89.6 & 97.2 & 100 & 100 & 100 \\
\cline { 2 - 10 }
\end{tabular}

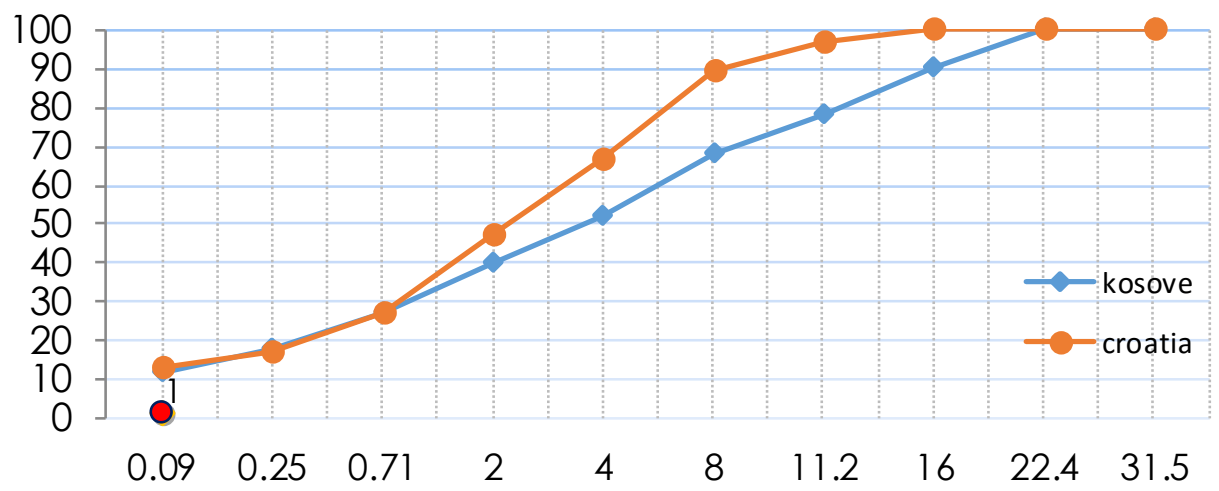

Figure 1. Curve granulomtris

\begin{tabular}{l|r|r|r|r|r|} 
Content of bitumen & \multicolumn{2}{c}{2.6} & \multicolumn{1}{c}{3.0} & \multicolumn{1}{c}{3.4} & \multicolumn{1}{c|}{4.2} \\
\hline Measure volume & 2372 & 2394 & 2412 & 2442 & 2435 \\
\hline The emptiness \% & 9 & 7.4 & 5 & 4.3 & 1.5 \\
\hline Fill empty & 30.2 & 46.4 & 56.8 & 67.3 & 88.2 \\
\hline Stability KN & 8.976 & 11.957 & 12.987 & 12.478 & 11.215 \\
\hline \multirow{2}{*}{ St-fllow wizard } & 5.11 & 3.209 & 2.882 & 3.236 & 3.96 \\
\hline \multirow{2}{*}{ St-wizard quotient } & 1.8 & 3.7 & 4.5 & 3.9 & 2.8 \\
\cline { 2 - 6 } & Table 8. Content of bitumen. & &
\end{tabular}

Therefore, these laboratory experiments can be taken as simulated experiments that would be conducted in Kosovo. Recycled asphalt was added to fractions of broken stone, stone Millie and quality bitumen for road 50/70 (according to EN 12591 eur code: 1999). 
Table 9 Measure of asphalt with \% recycled asphalt mas.

\begin{tabular}{|c|c|c|c|c|c|c|c|}
\hline Mixture of asphalt & $\begin{array}{l}\text { standard } \\
\text { mixture } \\
\text { of the } \\
\text { asphalt }\end{array}$ & $\begin{array}{r}\text { Mixt } \\
30 \% \text { r } \\
\text { as! }\end{array}$ & $\begin{array}{l}\text { with } \\
\text { ycled } \\
\text { alt }\end{array}$ & $\begin{array}{r}\text { Mixtu } \\
25 \% \mathrm{r} \\
\text { asp }\end{array}$ & $\begin{array}{l}\text { with } \\
\text { ycled } \\
\text { alt }\end{array}$ & $\begin{array}{r}\text { Mixtu } \\
20 \% \mathrm{r} \\
\text { asp }\end{array}$ & $\begin{array}{l}\text { with } \\
\text { ycled } \\
\text { alt }\end{array}$ \\
\hline Mixing components & 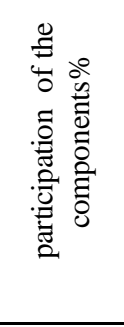 & 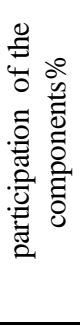 & 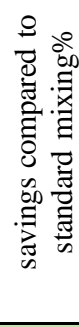 & 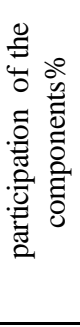 & 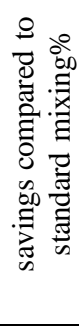 & 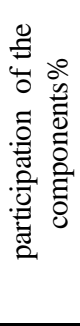 & 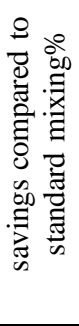 \\
\hline Sheath Stone & 6 & 2 & 66.67 & 2.5 & 58.33 & 3 & 50 \\
\hline Bitumen of roads & 3.9 & 2.38 & 37.5 & 2.61 & 31.25 & 2.85 & 25 \\
\hline Recycled asphalt & & 30 & & 25 & & 20 & \\
\hline 0/4 $\mathrm{mm}$ stone aggregate & 25 & 10 & \multirow{4}{*}{$30 \%$} & 13.5 & \multirow{4}{*}{$25 \%$} & 17 & \multirow{4}{*}{$20 \%$} \\
\hline 4/8 $\mathrm{mm}$ stone aggregate & 15 & 8 & & 9 & & 9 & \\
\hline $8 / 16 \mathrm{~mm}$ stone aggregate & 20 & 17 & & 16 & & 17 & \\
\hline Stone aggregate of $16 / 31.5 \mathrm{~mm}$ & 34 & 33 & & 34 & & 34 & \\
\hline
\end{tabular}

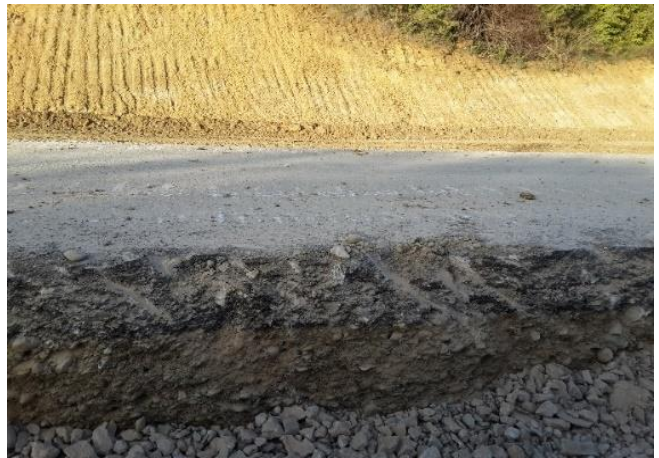

Fig 7. Waste of the removed asphalt layer on the road expanding Skenderaj - Komoran

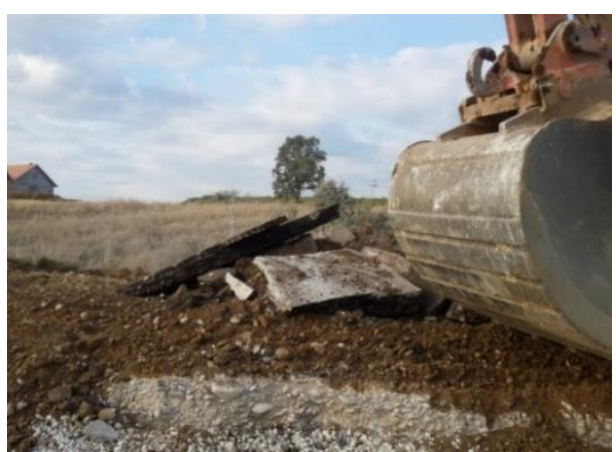

Fig 8. Waste of the removed asphalt layer on the road expanding Skenderaj - Komoran

On the basis of data and experiments presented in Kosovo is still construction of roads a priority, but the expansion of roads is being carried out in several directions, the expansion includes the route of the new which means should be overwrite the current structure of the road .

Therefore, there is a need that large amounts of the asphalt to be removed from those areas, should be mentioned some of the ways to be expanding as well as some others that are expected to expand. 
Table 10 Measure of asphalt with \% recycled asphalt mas.

\begin{tabular}{|c|c|c|c|}
\hline & $\begin{array}{l}\text { Measure of } \\
\text { asphalt with } \\
30 \% \text { recycled } \\
\text { asphalt mass }\end{array}$ & $\begin{array}{l}\text { Measure of } \\
\text { asphalt with } \\
25 \% \text { recycled } \\
\text { asphalt mass }\end{array}$ & $\begin{array}{l}\text { Measure of } \\
\text { asphalt with } \\
20 \% \text { recycled } \\
\text { asphalt mass }\end{array}$ \\
\hline $\begin{array}{l}\text { Density of the sample asphalt } \\
(\mathrm{kg} / \mathrm{m} 3) \\
\mathrm{EN} 12697-5\end{array}$ & 2509 & 2509 & 2495 \\
\hline $\begin{array}{l}\text { Density of mix asphalt }(\mathrm{kg} / \mathrm{m} 3) \\
\mathrm{EN} \text { 12697-6 }\end{array}$ & 2675 & 2685 & 2661 \\
\hline $\begin{array}{l}\text { participation of the gaps ( } \% \text { ) } \\
\mathrm{EN} \text { 12697-8 }\end{array}$ & 6.19 & 6.55 & 6.24 \\
\hline $\begin{array}{l}\text { gaps in the aggregate mass ( } \% \text { ) } \\
\mathrm{EN} 12697-8\end{array}$ & 15.74 & 15.51 & 15.85 \\
\hline $\begin{array}{l}\text { filling the gaps with bitumen ( \% } \\
\text { ) EN 12697-8 }\end{array}$ & 60.68 & 57.73 & 60.65 \\
\hline
\end{tabular}

Table11. Available recycling asphalt in Kosovo

\begin{tabular}{|l|l|l|r|}
\hline $\mathbf{N r}$ & Place (from) & Place (to ) & Distance in $\mathbf{~} \mathbf{m}$ \\
\hline $\mathbf{1}$ & Prishtinë & Mitrovicë & $36 \mathbf{K m}$ \\
\hline $\mathbf{2}$ & Prishtinë & Pejë & $82 \mathrm{Km}$ \\
\hline $\mathbf{3}$ & Prishtinë & Gjilan & $46 \mathrm{Km}$ \\
\hline $\mathbf{4}$ & Klina e Epërme-Skenderaj & Komoran - Drenas & $30 \mathrm{Km}$ \\
\hline $\mathbf{5}$ & Gjakovë & Prizren & $37 \mathrm{Km}$ \\
\hline & & & $\mathbf{2 3 1} \mathbf{K m}$ \\
\hline
\end{tabular}

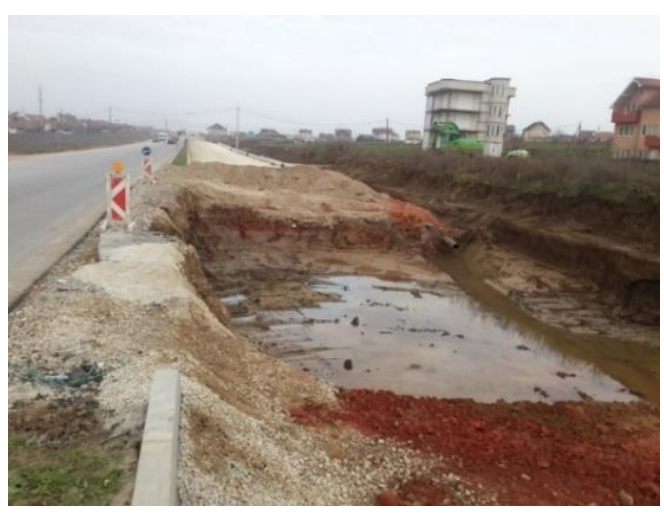

Fig 9.expansion of the road Prishtina-Mitrovica

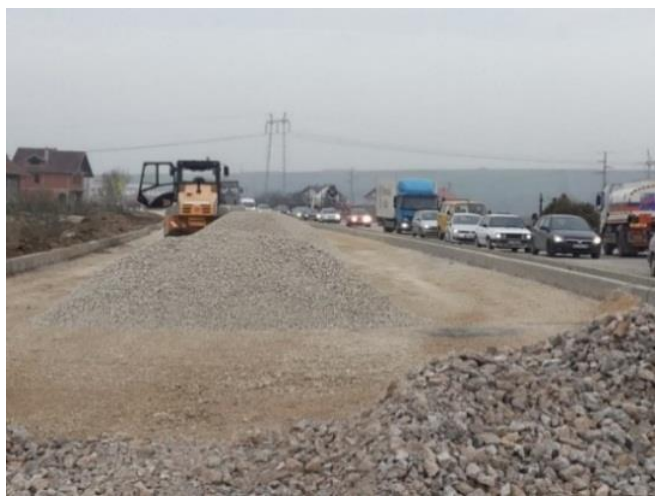

Fig 10. expansion of the road Prishtina - Mitrovica

During visite in saite we have noted that the thickness of asphalt, which has removed and can be recycled is $20 \mathrm{~cm}$ thickness, as well as the gravel thickness is average up to $30 \mathrm{~cm}$.

Acirdin those facts can be concluded that if it becomes recycled asphalt removed, will be lot savings first in diferent components of the asphalt . 


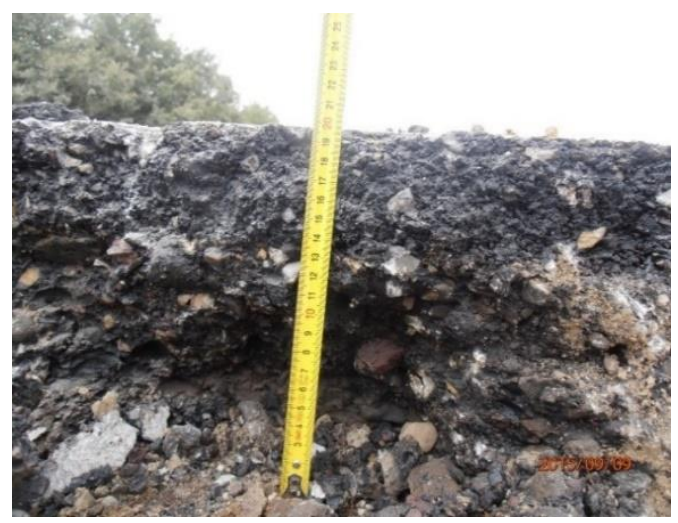

Fig 11. Thickness of the asphalt in place were its starting to remove in the road expanding Skenderaj

- Komoran

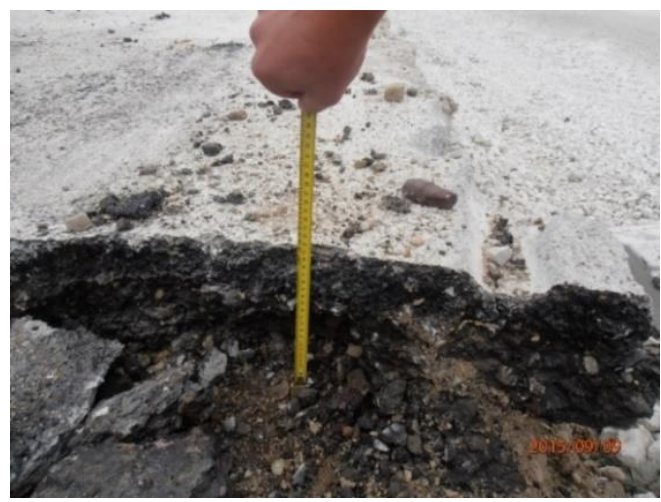

Fig 12. Thickness of the asphalt in place were its starting to remove in the road expanding Skenderaj - Komoran

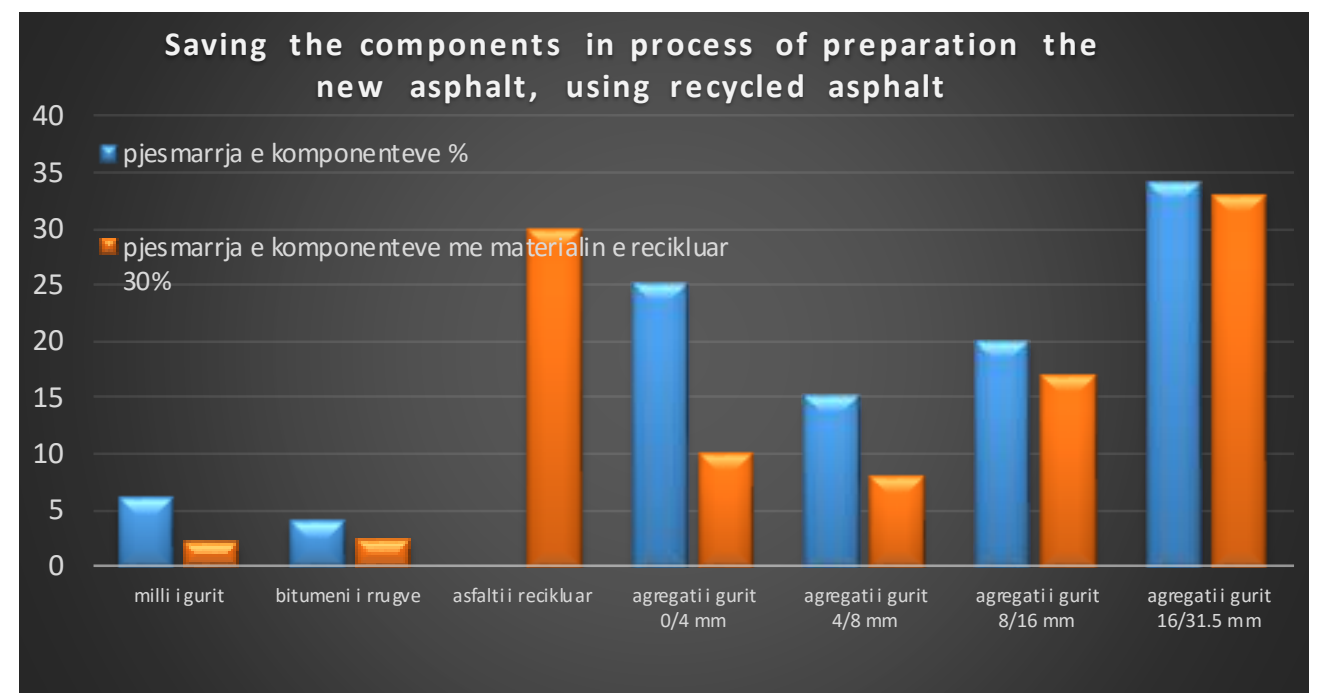

Figure 3. Saving the components in process of preparation the new asphalt, using recycled asphalt

\subsection{Economic benefits using recycled asphalt}

Laboratory tests obtained from asphalt recycling, which was obtained by milling and removal of layers of asphalt removed from parts of the roads that are being extended to just extensions in Kosovo are provided about $231 \mathrm{~km}$, according to these analyzes we can ascertain and found that the share of bitumen in asphalt mixture component participates with $4.75 \%$.

Recepture for designed for asphalt, which used as making the support layer BNS - 32s our goal is that, this percentage to be $3.8 \%$.

With the use of asphalt recycled with a share of $30 \%$ we use to measure that bitumen $37.5 \%$, and we have is the use of the amount of aggregate that is used for the preparation of asphalt will be: $66.67 \%$ of flour of stone, and $30 \%$ have use of fractions of aggregate: $0-4,4-8,8-16,16-31.3 \mathrm{~mm}$ We have also saving the main components of asphalt for asphalt-recycled participation with participation in mass by $25 \%$ and $20 \%$. 
Benefits from using recycled asphalt - case Kos ovo roads.

- Dimensions of roads that have begun to expand or are planned for expansion are $7 \mathrm{~m}$,

- The thickness of the asphalt to be removed is approximately $20 \mathrm{~cm}$,

- The distance of roads planned to expand is $231 \mathrm{Km}$,

- Amount of asphalt to be removed is about $323400 \mathrm{~m} 3$,

- Landfill site will be spared $323400 \mathrm{~m} 3$,

- Can be spared reserves of stone rocks $323400 \mathrm{~m} 3$,

- Will save more great power, which the former used for processing, transport and placement of aggregate in asphalt plant.

Construction of new asphalt

- $\quad$ Aggregate spared if used 30\% of recycled asphalt $478170 \mathrm{~m} 3$ ( $23 \mathrm{~m}$ )

- $\quad$ Bituminous spared if used $30 \%$ of recycled asphalt 13.388,760 400 liter

SAVINGS WILL BE MILLIONS AS THE FINANCIAL ASPECT, ALSO AS WELL AS ECOLOGICAL ASPECT TOO.

\section{Conclusions and Recomendations:}

In this paper were analyzed the results obtained in the laboratory examination of the materials in Croatia, these tests are simulated and the same receipts used in Kosovo for the preparation of asphalt, are also analyzing the quantities of asphalt recycled in percentage $30 \%, 25 \%$ and $20 \%$, based on this analysis and research can be verified as follows:

- Using recycled asphalt will have to reduce the storage of asphalt removed from areas where routes expanded or repaired roads,

- Reduced amount of aggregate used for preparation of asphalt, there is a reduction in energy and reduction of greenhouse release energy, which we need to be excavated, milled, and transported to the asphalt plant.

- Reduced amount of that production bitulitet trailer considerable energy we need,

- Protecting the environment from waste from bitulitit that are in asphalt away, where these wastes are harmful to the surroundings as well as flora and fauna in places where stored, where according visit and monitoring in Kosovo these wastes are deposited in place deposition, without specify ing severely damaging the surrounding ecosy stem,

- The use of asphalt recycling, reduces from 25 to $30 \%$ of the energy required in the production of asphalt, which have the savings noted the release of $\mathrm{CO} 2$ into the atmosphere, diversity and mixture of asphalt recycling is difficult to control \% dosage and millie stone aggregate and bitulitit distinction, necessary for preparation of asphalt for the road support layer;

- Issuance of bitulitit of recycled asphalt, have the deviation in up to $13.99 \%$ of the amount needed for the preparation of asphalt;

- The deviation of the granulometric curve of samples taken by $25 \%$ of recycled asphalt sizes appear in parts of the aggregate occurs in aggregate size of $0.71,8.00 \mathrm{~m}$ and $20.11 \mathrm{~mm}$ until 22:40 where granulometric curve has won a composition with thick aggregate asphalt mixture compared with the projected normal asphalt;

- Reducing the amount or portion of the recycled asphalt it is much easier to achieve value (designed) to mix asphalt;

- All laboratory samples to analyze the mix asphalt designed and samples of asphalt designed by adding amounts of asphalt recycled in percentage set at 30\%, 25\% and $20 \%$, meet the limit values specified by standards European preparation of asphalt laid for the roads with large loads to transport;

- Savings in the amount of the sum of the components of asphalt (bitumen gravel, sand and powdered stone) depends primarily on the type of asphalt that is recycled,

Taking values bitulitit to layer the final asphalt, where the percentage of bitulitit ranges on average from $4.75 \%$ to Bitumen, the use of recycled asphalt for savings brought from $25 \%$ to $37.5 \%$ depending on the amount of recycled asphalt was taken as part of the composition of asphalt designed. 


\section{Recommendations}

1. Recommended the Ministry of Infrastructure, to prepare a Law for recy cling of inert materials with a specific gravity of the recycling asphalt awarded.

2. Non-compliance with this law, penalties against violators of the trailer

3. Ministry of Infrastructure should be obliged companies that deal with the production of asphalt use of recycled asphalt, obliging them to a certain percentage, as well as to comply with recycling companies to support by the ministry.

4. The amount of the use of recycled materials to define the working contract, acording type of recycled material, ways of recy cling and the amount of recy cling.

Results of asphalt mixtures using recycled asphalt to produce bitumen asphalt layers type BNS-32s in very heavy traffic load shows that this technical solution is justified by the economic and ecological aspects.

Future research should focus on analy zing the possibility to produce such a mixture of asphalt mixing and production of new shares and testing recycled asphalt applications in other asphalt mixtures.

\section{References}

1. Šimun, M., Škerlj, S: Reconstruction of asphalt pavement in Croatia, 10 Slovenian Congress on Roads and Transport, Portoroz, 2010.

2. Drezgić, S: Reform of the system of financing public roads, the Croatian Treasury, RFF, Zagreb , 2008., str. 22- 28.

3. Arand, W: Behavior of asphalt aggregate mixtures at low temperatures, 1990.

4. Schwabe, Ž:Recy cling of asphalt road pavements 2009., M anagement of transport infrastructure, Civil Engineering, Department for Transportation 2009.

5. Dridarski, D: Recycling existing asphalt pavements .

6. Schwabe, Ž., Halle, M: The process of cold recycling in road reconstruction, Collection 2008.

7. HRN EN 12697-1:2003 Bituminous mixtures - Test methods for hot mix asphalt process - Part 1: Soluble binder content.

8. HRN EN 12697-8:2003 Bituminous mixtures - Test methods for hot mix asphalt process eighth part: Determination of the voids in asphalt mixtures $\backslash$

9. ASPHALT IN FIGURES 2013 - www.eapa.org 